Транспозоноподобная структура генома вируса саркомы Рауса - налине фланкируюших $L T R$, гена $s a r c$, находящсгося под сильным иромотором, обусловливают перспектиниость использования плазмиды $p A T V-8$ в исследованиях стадие- и тканеспегифнчности экспрессии генов, стабильности структуры трансгеномов, взанмодействия трансгеномов и генома клеток организма, несущего трансгеном.

\title{
THE TRANSGENIC MICE CONTAINING pATV-8 AND pBR322 PLASMIDS
}

A. P. Solomko, A. V. Ryndich, T. G. Tilok, L. M. Morozova, I. N. Vagina, L. I. Chashchina, S. V. Evsykov, I. V. Kirichenko, N. A. Sarapina

Institute of Molecular Biology and Genetics, Acadeny of Sciences of the Ukrainian SSR, Kiev

Sum mary

The transgenic mice containing recombinant $p A T V-8$ plasmid, produced by insertion of the provirus DNA of RSV into pBR322 were obtained. The type of the transgene DNA inheritance cannot be explaincd by the insertion of its copies into one chromosomal site. in cortan transgenic mice lines the phenotypic disorders were observed.

1. Хесин P. Б. Непостоянство генома.- . : Наука, 1984.-472 с.

2. Restriction endonuclease and nucleotide sequence analysis of molectlarly cloned uninlegrated avian tumor virus DNA: structure of large terminal repeats in circle junctions / R. A. Katz, C. A. Omer, G. H. Weis et al.//J. Gen. Virol--1982.-42, N 1.P. $346-351$

3. Rescue of a $t k$-plasmid from transgenic mice reveals its episomal transmission/U. Kiessling, K. Bccker, M. Strause et al.//Mol. and Gen. Gencl.- 1986.-204, N 2.P. $328-333$.

4. Germ line transmission of autonomous genetic elements in transgenic mouse strains / M. Rassoulzadegan, P. Leopold, J. Vailly, F. Cuzin //Cell.-1986.-46, N 4.P. 513-519.

5. Gordon $J, W$. A foreign dihydrofolate reductase gene in transgenic mice acts as a dominant mutation // Mol. and Cell. Biol--1986.-6, N 6.- P. 2158-2167.

6. An inherited limb deformity created by insertional mutagenesis in transgenic mouse/ R. P. Woychik, T. A. Stewart, L. Y. Davis et al.// Nature - 1985.-318, N 6041.P. $36-40$

7. Prenatal lethalities in mice homozygous for human growtl hormone sequences integrated in the germ line / E. F. Wagner, L. Covarrubias, T. A. Stewart, B. Mintz// Cell- - 1983.-35, N 3.- P. $647-655$.

8. Insertion of retrovirus into first intron of $\mathrm{I} / \mathrm{I}$-collagen gene leads to embryonic lethal mutation in mice/K. Harbers, $M$. Kuehn, H. Delius, R. Jaenisch// Proc. Nat. Acad. Sci. USA -- 1984-81, N 5-P. 1504-1508.

9. Covarrubias L., Nishido Y., Mintz B. Early postimplantation embryo lethality due to DNA rearrangements in a transgenic mouse strain//Ibid-1986.-83, N 16.P. $6020-6024$.

YIIK $5 \div 7.152: 577.151$

\section{ИНДУЦИРУЕМАЯ ОЛИГОНУКЛЕОТИДНЫМ СУБСТРАТОМ ДИМЕРИЗАЦИЯ ЭНДОДЕЗОКСИРИБОНУКЛЕАЗЫ МvаІ}

\section{Л. Г. Овечгина, С. Р. Попова, В. В. Зиновьев, Д. П. Вайткявичюе,} А. А. Янулайтис, Ю. А. Горбупов, Э. Г. Малыгин

Эндонуклеазы тила II, как правило, узнают симметричную нуклеотидную последовательность и имеют димерную структуру типа $\alpha_{2}$ [1]. Имеются, однако, исключения например, для эндодезоксирибонуклсаз $B g l I$ и $B s p I$ показано, что они являются мономерными белками [1].

Исследованис таких эндонуклеаз иредставляст спсциальный нитерес, так как структура фермента, взаимодействуюпего с симметричным субстратом, должна иметь элементы симметрик. Один из возможиых способов образования симметричной струк- 
туры - димеризация субъединиц, что было показано, например, для метилазы Ecodam, имеющей симмстричный сайт узнавания [2] .

Целью данной работы являлось определение молекулярной массы эндонуклеазы Mval в денатурирующих и нативных условиях, а также в присутствия синтетических опигонуклсотидов.

Олигодезоксирибонуклеотиды 5'-dAACCTGGAA (I), 5'-dTTCCAGGTT (II) и $5^{\prime}$-dCGGATCCG (III) были синтезированы фосфотриэфирным методом [3] и содержали на 5'-конце свободную гидроксильную группу. Эквимолярная смесь олигонуклеотидов
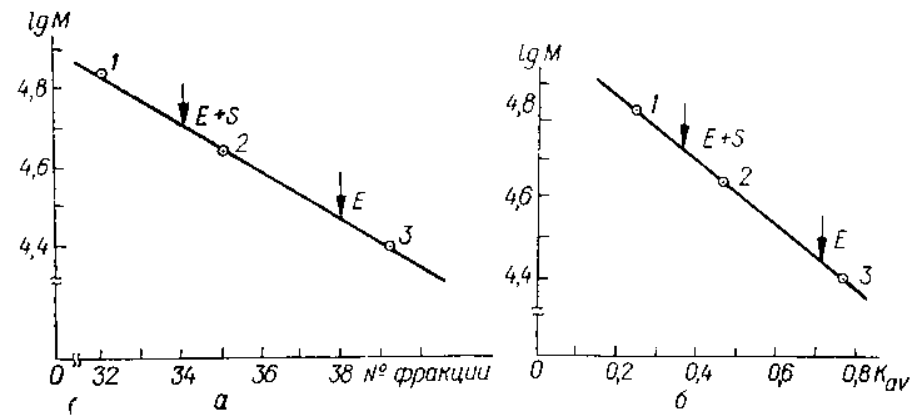

Опредсленнс молекулярной массы эндонуклеазы $M v a I(E)$ и комплекса этого фермента с субстратом $(E+S)$ при температуре $5-7^{\circ} \mathrm{C}: a-$ - льтрацентрифугирование в градиенте концентрацин сахарозы; 6 - гель-фильтрация на сефакриле S-200. В качестве субстрата $(S)$ использовали двухцепочечный олигонуклеотид, содержащий участок узнавания для эндонуклеазы Mval в концентрация 1,5 мкM. 1-3-положение маркерных белков: БСА (68000), овальбумин (45000) и химотрипсиноген (25000) соответственно Molecular weight determination endonuclease $\operatorname{MvaI}(E)$ and its complex with the substrate $(E+S)$ at the temperature of $5 \cdot 7^{\circ} \mathrm{C}: a-$ sucrose density gradient centrifugation; 6 -gel filtration on sephacryl S-200 column. Oligonucleotide complex $(1.5 \mu M)$ containing recognition site of endonuclease $M v a I$ was used as a substrate $(S)$. $1-3$ - the marker proteins: bovine serum albumin (68000), ovalbumin (45000) and chymotrypsinogen (25000), respectively

I и II приводит к образованию дуплекса, содержащего в центре последовательность узнавания 5 ...C-C-T-G-G-... для эндонуклеазы Mval. Самокомплементарный ок... $\mathrm{G}-\mathrm{G}-\mathrm{A}-\mathrm{C}-\mathrm{C}-\ldots 5^{\prime}$

тануклеотид III образует двухцепочечную структуру, в которой отсутствует участок узнавания для этого фермента.

Эндонуклеазу MvaI выделяли по методу $[4,9]$. Для определения молекулярной массы фермента использовали методы электрофореза в денатурирующих условиях [5], гель-фильтрацин [6] и центрифугирования в градиенте концентрации сахарозы от 10 до $30 \%[7,8]$.

Растворы сахарозы готовили в буфере А (20 мМ К-фосфат, $\mathrm{pH} 7,5,10$ мМ ЭДТА, 7 нМ 2-меркаптоэтанол, $0,6 \mathrm{M} \mathrm{NaCl}$ ). На градиент сахарозы объемом 5 мл наслаивали 100 мкл препарата эндонуклеазы Mval с концентрацией белка около 10 мкг/мл. Центрифугирование проводили на ультрацентрифуге «Beckman» L5-75 (США) со скоростью 45000 об/инн при температуре $5{ }^{\circ} \mathrm{C}$ в течение 20 ч. После центрифугирования градиент раскапывалн на фракцин по 80 мкл. Активность фермента определяли по методу, приведенгму в работе [9]. По калибровочному графику определяли молекулярную массу фермента.

Для гель-фильтрации использовали колонку ( $h=10 \mathrm{~cm}, d=0,25 \mathrm{~cm})$ с сефакрилом S-200, уравновешенную буфером А с добавлением 100 мкг/мл БСА, и наносили 2 мкл препарата эндонуклеазы с концентрацией белка 50 мкг/мл. Собирали фракции по 25-30 мкл и определяли в каждой ферментативную активность [9]. Bсе необходимые измерсния оптической плотности при 280 им проводили на спектрофотометре «Обь» (ССCP)

По дангым электрофорсза, в денатурирующих условиях полученный препарат эндонуклеазы $M v a I$ представляет собой гомогенный белок, состоящий из одной субъединицы с молекулярно̆̆ массой $31300 \pm 400(n=3)$. Близкие значения получены при цептрифугировани фермента в градиенте концентрации сахарозы $27700 \pm 2300 \quad(n=3)$ (рисунок, a) и методом гель-фильтрации $27400 \pm 1900(n=4)$ (рисунок, б).

Следует отметить, что при понижении концентрации $\mathrm{NaCl}$ до $0,1 \mathrm{M}$ в буфере $\mathrm{A}$ наблюдастся знатитсльное увеличение молекулярной массы фермента в несколько раз 
и одновременно паденис сго активности. Это, по-видимому, связано с агрегацией белка. Уменыцение активности фермента в связи с его агрегацией ранее было показано для эндонуклеазы EcoRJ [10]. Влиялис концентрации $\mathrm{NaCl}$ иа измснеине субъединичной структуры фермента н сго активность требует дальнейних исследований.

При щентрифугировании фсрмента в градиентс концентрации сахарозы, содержащем равнораспределенный по всему объему девятичленный олигонуклеотидный дуплекс, наблюдается увеличенне молекулярной массы фермента до $53100 \pm 3000$ ( $n=7$ ) (рисунок, a). При добавленић 1,5 мкM олигонуклеотида III, не содержащего участка узнавания рестриктазы $\mathrm{Mval}$, молекуляргая масса фермснта также увелитивается до 51000. Ранее мы наблюдали димеризацию нетилазы Ecodam в присутствии олигонуклеотидного дуплекса, не содержашего участка узнавания [2]. Таким образом, димеризация эндонуклеазы Mval и метилазы Ecodam происходит, по-видимому, при взанмодействии с любым участком двухцепочечной ДНК.

При гель-фильтрации рсстриктазы MvaI на колонке с сефакрилом S-200, предварительно промытым буфером А и солержащим девятичленный олигонуклеотидный дуплекс, получено зиачение молскулярной массы фермента 52500 (рисунок, б), что полностыо совпадает с данными, которые дает метод ультрацентрифугирования.

Это значение несколько меңьше тсоретически возможной молекулярной массы, равной 62000, для фермент-субстратного комплекса, содержащего две субъединицы фермента. Такое различис может быть связано с существованием равновесия между комплексом и свободным ферментом [2]. Возможно также, что это несоответствие является следствием использования белковых калибровочных кривых для определения молекулярной массы белок-нуклеинового комплекса. Однако, поскольку в настоящей работе использовали девятичленный олигонуклсотидный субстрат с небольшой молекујярной массой по сравнению с ферментом, трудно предположить значительные изменения глобулярпости белково-нуклеиновых частп. Использование белковых маркеров при определении константы диссоциации фермент-субстратных комплексов методом гельфильтрации в литературе известно [11].

Таким образом, наблюдасмое увеличенис (практически в два раза) молекулярной массы рестриктазы Mval в присутствии двухцепочечного дуплекса по сравнению со свободным ферментом связано с образованием димерной формы фермента. По-видимому, димеризапия эндонуклеазы Mval при взаниодействии с ДНК является необходимой стадией образования каталитически активнои формы фермент-субстратного комплекса. Возможно, это утверждение справедливо и для рсстриктаз $B g l l$ и $B s p I$, выделенных в виде мономерных белков [1].

\section{ENDONUCLEASE MvaI DIMERIZATION INDUCED BY THE OLIGONUCLEOTIDE SUBSTRATE}

L. G. Ovechkina, S. R. Popova, V. V. Zinoviev. D. P. Vaitkevicius*.

A. A. Janulaitis*, Yu. A. Gorbunov, E. G. Malygin

All-Union Research Institute of Molecular Biology,

Koltsovo, Novosibirsk Region

* Research and Production Amalgamation «Ferment», Vilnius

Sum mary

Molecular weight of the endonuclease $M v a l$ was determined by the method of gel electrophoresis under denaturing conditions. The enzyme consists of a single polypeptide chain will molecular weight of $31300 \pm 400$ dalton. Similar data are obtained by gel filtration and sucrose density gradient centrifugation. In the presence of substrate the oligomucleotide molecular weight of endonuclease $M v a I$ increases up to $53000 \pm 3000$ dalton, that is related to protein dimerization during the formation of the enzyme-substrate complex.

1. Modrich $P$. Studies on sequence recognition by type II restriction and modification enzymes // Crit. Revs Biochem-1982-13, N 3.-P. 287-323.

2. Нзучение индуцированиых субстратом изменений в состоянии метилазы Ecodam ме. тодом малоугтового рентгеновского рассеяния /Ф. В. Тузиков, Л. Н. Яшина, В. В. Зиновьев и др. // Молекуляр. биология.- 1986.-20, № 4-C. $1002-1007$.

3. Hirose T., Crea R. Itakura K. Rapid synthesis of trideoxyribonucleotide blocks // Tetrahedron I.ett - 1978.-28.-P. 2449-2452. 
4. thvestigalion of restriction-modification enzymes from $M$. variaus $R F L 19$ with a new type of specificity toward modification of substrate/V. Butkus, S. Klimasanshas. D. Kersulyte et al. // Nucl. Acids Res. - 1985.-13, N 16.- P. 5727-5746.

5. Laemmli $U$. K. Cleavage of structure proteins during the assembly of the head bacteriophage T4// Nature.-1970.-227, N 5259.- P. 680-685.

6. Siegel L. M., Monty K. G. Determination of molecular weights and trictional ratios of proteins in impure systems by usc of gel-filtration and density gradient centrifugation // Biochim. el bioply's. acta - 1966. -112, N 2.- P. 346-362.

7. Herman G. E., Modrich P. Escherichia coli dam methylase. Physical and catalytic properties of the homogeneous enzyme //J. Biol. Chem.-1982.-257, N 5.P. 2605-2612.

8. Martin R. G., Ames B. N. A method for determining the sedimentation bchavior of enzymes: application to protein mixtures // Ibid-1961.-236. N 5.- P. 1372-1379.

9. Янулайтис А. А., Вайткявичюс Д. П. Новый методическпй подход к разработке получения рестрикционных эндонуклеаз. Разработка схемы выделения гоміогенгого препарата рестриктазы Mval// Биотехнология.- 1985.- o 1.-C. 39-51.

10. Alves J. Mechanistische Untersuchungen zur Spaltung von Oligodesoxynucleotiden durch die Restriktionsendonuklease EcoRI.- Hannover: Lniversitat Hannover, 1984.S. $16-24$

11. Frankel A. D., Ackers G. K., Smith H. O. Measurement of DNA-protein cquilibria using gel chromalography: application to the Hinfl restriction endonuclease// Biochemistry.-1985.-24, N 12.- P. 3049-3054

ВНнИ молскуляр. биологин,

пос. Кольщово Новоснб. обл.

По.тучен 14.07 .87

\section{ПЮДОБИЕ ДНК-УЗНАЮЩИХ СТРУКТУР АКТИВАТОРА КООРДИНИРОВАННОЙ ТРАНСКРИПЦИИ ГЕНОВ, КОДИРУЮЩИХ ФЕРМЕНТЫ БИОСИНТЕЗА АМИНОКИСЛОТ У ДРОЖЖЕЙ, РЕГУЛЯТОРОВ ДИФФЕРЕНЦИРОВКИ КЛЕТОК ДРОЖЖЕЙ И РЕГУЛЯТОРОВ РАЗВИТИЯ И МОРФОГЕНЕЗА}

\section{Б. В. Шестопалов}

Введение. у црожжей Saccharomyces cerevisiae супествуст координация транскрипции гелов, коднрующих фсрмелты биосинтеза амилокислот [1]. Непосредственным активатором коордннированной транскрипции является белок GCN4 [2], причем активация

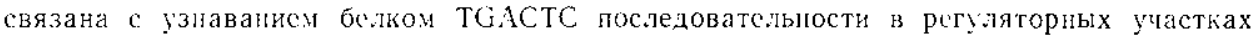
активируемых генов [3]. Авторы работы [4] предирнияли попытку опрсдслить, к какому нз дпух известных вндов ДНК-узнаюшей структуры, «па.льценидиоӥ» или спира.Іь-изгиб-спираль, огюосится ДНК-узнающая структура белка $G C N 4$ и где она

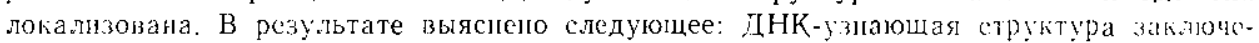
на в С-копцевом домсне бслка - сггмнте 222-281; «паныевидная» структура в ДНКузпаюем домсне певозможла, так как в сго аминокислотной после,ьовательності пет ключевых для пее остатков; присутствик структуры спираль-изгиб--слиральь, локалнзовапной по данным предсказания вторичной структуры ДНК-узпающего домєна (спираль 244-261, изгиб 262-265, спираль 266-278), сомнителыю: спнрали длинисе обычных, аминокислотная последователыюсть не гомологична амннокислотыы послсдовательностям структур спираль-изгиб-спираль. В итоге авторы прншін к вынолу, что волрос о виде ДНК-узнающей структуры бслка $G$ СА'4 и ее :1канизащи остастся открытым.

В настоящей работс представлены дапны, на основании которых сдслано заклютение, что белок GCN4, возможюо, узнаст ДНК с помоцью ДНК-узнаюшей структуры спираль-изгиб-спираль, локализованной в сегменте аминокислотюой послсдовательности 256-278, и ДНК-узнающая структура белка GCN4 подобна ДНК-узнаюшім структурам белков MATal и MAT 22 - регуляторов дифференцировки клеток дрожжей, и гомеодоменсодсржащих бслюов- регуляторов развития и морфогенсза.

Методы. Использовали нсобходимые стереохимические условня сущсствозания ДНК-узнаюшей структуры спираль-изгиб- спираль, описаныые в נашсы статье [5] 